\title{
A New Approach to NLRB Jurisdiction over the Employment Practices of Religious Institutions
}

The constitutional limits on National Labor Relations Board ("NLRB") jurisdiction over the employment practices of religious organizations are unclear. In National Labor Relations Board $v$. Catholic Bishop of Chicago, ${ }^{1}$ the Supreme Court read congressional intent behind the National Labor Relations Act ("NLRA") in a very narrow fashion in order to skirt the "difficult and sensitive"3 question of whether the religion clauses of the first amendment bar NLRB jurisdiction over the employment practices of religious organizations in general, and parochial schools in particular. The Court refused to construe the NLRA to reach parochial school teachers, concluding that Congress had not expressed a clear, affirmative intent to extend NLRB jurisdiction over religious organizations. ${ }^{4}$ Since Catholic Bishop, Congress has not clarified its intent under the NLRA sufficiently to satisfy the courts. The courts of appeals therefore have become the primary decision makers as to the precise extent of NLRB jurisdiction over organizations with religious affiliations.

The Supreme Court's decision in Catholic Bishop and the emerging approach of the courts of appeals reflect two markedly different solutions to the problem of NLRB jurisdiction over the employment practices of religious organizations. Recognizing that the impact on the organization depended on the employees involved, Catholic Bishop concentrated on the nature of the employee's activity, analyzing potential free exercise problems with NLRB jurisdiction in terms of the activities of particular employees in particular jobs. ${ }^{5}$ By contrast, the courts of appeals have analyzed accommodation of religiously affiliated organizations by reference to the organization as a whole, distinguishing between

1440 U.S. 490 (1979).

29 U.S.C. $\$ \$ 151-69$ (1982 \& Supp. 1986).

3 Catholic Bishop, 440 U.S. at 507.

1 Id. at 506.

Id. at 501-04. 
"pervasively religious" and secular institutions. If the institution is deemed to be "pervasively religious," the courts assume that first amendment rights will be infringed by the NLRB's assertion of jurisdiction over any of the organization's employment activities. On the other hand, if the organization's character, goals, or methods are deemed secular, NLRB jurisdiction over all of its employment activities is held not to violate the religion clauses.

This comment argues that the "organizational" test developed by the courts of appeals is constitutionally flawed and that only the employee-based approach offers a viable solution to the accommodation problems identified in Catholic Bishop. The organizational approach to exemption is overinclusive because even those employees who perform purely secular functions will be exempted from the operation of the NLRA if their employer is deemed "pervasively religious"; and the test is underinclusive in its accommodation of individual free exercise rights because even an employee who performs religious functions will be covered by the NLRA if the organization for which she works is not deemed pervasively religious. Finally, because the organizational approach focuses on whether an institution is "pervasively religious," it requires the courts to investigate, evaluate, and apply the doctrine of the religion in question.

As an alternative to the flawed "organizational" test, this comment proposes a two-step inquiry focusing on the activities of the employees in question. The fact finder should determine, first, whether the employee was hired from the secular marketplace, and second, whether her employment activities can be distinguished from activities ordinarily performed in a secular setting only by reference to the theology of the religious organization. If the answer to both these questions is affirmative, or if an affirmative finding on one prong sufficiently outweighs a negative finding on the other, then Title VII, the NLRA, and other fair labor statutes are applicable. Otherwise, the particular activities in question should be exempt. This approach avoids the overinclusiveness and underinclusiveness of the organizational test, as well as the need for a court to become entangled in theological questions in determining the extent of NLRB jurisdiction.

- Denver Post of the Nat. Soc. v. N.L.R.B., 732 F.2d 769, 773 (10th Cir. 1984).

$?$ Id. 


\section{NLRB JURISDiction and Statutory Accommodation}

A. Accommodation under Section 19 of the NLRA

The NLRB implements the NLRA by exercising its various powers, such as determining appropriate collective bargaining units $^{8}$ and holding hearings on unfair labor practices. ${ }^{9}$ The NLRB may exercise jurisdiction over employers and their agents. Statutory exceptions to NLRB jurisdiction include eight specific employer-based exceptions ${ }^{10}$ and only one employee-based exception, section 19.

Congress enacted section 19 of the NLRA in 1980, one year after the Catholic Bishop decision, in order to address the first amendment problem posed by union shop employees of ordinary, secular businesses whose religious beliefs precluded union membership. Section 19 provides:

Any employee who is a member of and adheres to established and traditional tenets or teachings of a bona fide religion, body or sect which has historically held conscientious objections to joining or financially supporting labor organizations shall not be required to join or financially support any labor organization as a condition of employment."

If employees opt out of union membership for religious reasons under section 19, they may be required to donate an amount equal to union dues to a "nonreligious charitable fund."12

It is noteworthy that Congress chose to create an employeebased exemption to NLRB jurisdiction, rather than the employerbased exemption that it has chosen in all other contexts. This indicates that Congress foresaw extension of NLRB jurisdiction over religious organizations, and that it chose to accomodate the free exercise rights of individual employees through section 19 while

29 U.S.C. § 159(b) (1982).

- Id. at $\$ 160(a)$.

10 The following employers are exempted from NLRB jurisdiction: the United States, wholly owned government corporations, Federal Reserve banks, states and their political subdivisions, persons subject to the Railway Labor Act, and labor organizations and their officers and agents (when they are not acting as employers). Id. at $\S 152(2)$.

In 1974, Congress repealed a limited exception for non-profit health care institutions. Pub. L. No. 93-360, 88 Stat. 395 (1974). It thereby confirmed that all employers, except for the eight employers listed above, were included under the NLRA.

1129 U.S.C. \& 169.

12 Id. Section 19 further stipulates that, if this employee asks the union to use the grievance-arbitration procedure on her behalf, she may be required to pay a reasonable fee for this service. Id. 
declining to enact a blanket exemption providing additional accomodation for the organizations themselves. Congressional decisions of this sort are entitled to particular deference.

\section{B. The Public Policy of the NLRA}

There is a compelling public interest in applying the good faith collective bargaining requirement of the NLRA uniformly to all employers and labor unions. ${ }^{13}$ Of equal importance is the fact that the government's jurisdiction over labor regulation is essential to maintaining the "peace and good order"14 that Jefferson held to be the concern of the state. As the Supreme Court noted fifty years ago in N.L.R.B. v. Jones \& Laughlin Steel Corp., ${ }^{15}$

[e]xperience has abundantly demonstrated that the recognition of the right of employees to self-organization and to have representatives of their own choosing for the purpose of collective bargaining is often an essential condition of industrial peace. Refusal to confer and negotiate has been one of the most prolific causes of strife. This is such an outstanding fact in the history of labor disturbances that it is a proper subject of judicial notice and requires no citation of instances. ${ }^{16}$

Moreover, the reason for the creation of the NLRA was to correct the inequality of bargaining power between employees and employers that substantially burdened the flow of interstate commerce. ${ }^{17}$ Consequently, because labor regulation is so clearly within the government's power, Congress vested the Board with the fullest jurisdictional breadth constitutionally permissible under the commerce clause. ${ }^{18}$

That regulation of religiously affiliated institutions' secular employment activities falls within the government's domain is further proven by the courts' rejection of claims that the Act's mandatory bargaining ${ }^{19}$ and union shop ${ }^{20}$ provisions must yield to

${ }^{13}$ Cap Santa Vue, Inc. v. N.L.R.B., 424 F.2d 883, 890 (D.C. Cir. 1970).

14 See Thomas Jefferson, An Act for Establishing Religious Freedom (1786), in Joseph L. Blau, ed., Cornerstones of Religious Freedom in America 77-78 (1964).

1s 301 U.S. 1 (1937).

16 Id. at 42.

17 See 29 U.S.C. § 151.

18 Labor Board v. Reliance Fuel Corp., 371 U.S. 224, 226 (1963).

${ }^{18}$ Cap Santa Vue, 424 F.2d at 890.

20 Yott v. North American Rockwell Corp., 501 F.2d 398, 403 (9th Cir. 1974), reaff'd on appeal from remand, 602 F.2d 904 (1979); Hammond v. United Papermakers and Paperworkers Union, 462 F.2d 174, 175 (6th Cir. 1972); Linscott v. Millers Falls Co., 440 F.2d 14, 17-18 (1st Cir. 1971). 
conflicting religious beliefs, except to the extent provided in section 19. However, even section 19 does not prevent formation of union shops where religious objections are made. Finally, the Court has been unyielding in its application of fair labor practice statutes such as Title VII and the Fair Labor Standards Act to religious organizations' secular employment activities. ${ }^{21}$

\section{Catholic Bishop and Mandatory Accommodation under the NLRA}

Roman Catholic dioceses operate a variety of primary and secondary schools, in which instruction is provided both by members of religious orders and by lay teachers employed by the dioceses. In 1974 and 1975, unions sought to conduct representation elections in secondary schools operated by the Catholic Bishop of Chicago and by the Diocese of Fort Wayne-South Bend, Indiana. ${ }^{22}$ The church challenged the organizing efforts on first amendment grounds in Catholic Bishop of Chicago. ${ }^{23}$ In ruling on the scope of its jurisdiction, the NLRB rejected the diocese's argument that NLRB jurisdiction over the schools' employment of lay teachers violated the first amendment. The Board's decision focused exclusively on the character of the organizations involved, concluding that the organizations were not "completely religious" because they performed instructional functions that were, in part, secular. ${ }^{24}$ On appeal, the Seventh Circuit held that this exercise of jurisdiction was an abuse of NLRB discretion. The court rejected the "completely religious" test, arguing that it would lead to extension of NLRB jurisdiction to all church-operated schools, since those schools all offered instruction in secular subjects as well. ${ }^{25}$

The Supreme Court agreed that the NLRB had abused its discretion in exercising jurisdiction over these teachers, and endorsed the Seventh Circuit's rejection of the Board's organizational test. Significantly, the Court phrased the inquiry differently than the NLRB had, focusing on the activities of teachers rather than solely on the character of the schools. ${ }^{26}$ But rather than reach the consti-

21 See Tony \& Susan Alamo Foundation v. Sec. of Labor, 471 U.S. 290 (1985).

${ }^{22}$ Some of the institutions involved were "minor seminaries" designed primarily to train students for the priesthood, and one condition of entry for students was recommendation by a parish priest as "having a potential for the priesthood or for Christian leadership." 440 U.S. at 492.

23 220 NLRB 359 (1975).

24 Id.

${ }^{2 s}$ Catholic Bishop of Chicago v. N.L.R.B., 559 F.2d 1112, 1118-19 (7th Cir. 1977).

${ }^{26} 440$ U.S. at 500 ("[T]he question . . . is whether Congress intended the Board to 
tutional issues, the Court simply noted a "significant risk" that exercise of NLRB jurisdiction might cause first amendment problems and "decline[d] to construe the Act in a manner that could in turn call upon the Court to resolve difficult and sensitive questions arising out of the ... First Amendment."27 Finding no affirmative statement in the statute that parochial school teachers were to be covered by the NLRA, a slim majority of the Court observed that "an Act of Congress ought not be construed to violate the Constitution if any other possible construction remains available."28

The Court in Catholic Bishop was especially worried about the possibility that NLRB jurisdiction over these parochial schools would illegitimately entangle the government in religious affairs. ${ }^{29}$ The Court suggested that the NLRB's failure adequately to consider whether or not risks of entanglement were present in these cases was caused by the Board's use of a per se organizational test." The Court focused on "the critical and unique role of the teacher in fulfilling the mission of a church-operated school,"31 and it feared that NLRB evaluation of unfair labor practice charges and certification of mandatory bargaining subjects might involve the Board in disputes over matters of religious belief between the teachers and the religious authorities of the schools. ${ }^{32}$ Further, the

have jurisdiction over teachers in church-operated schools.") (emphasis added). The dissent also focused on the activities of the teachers, rather than the nature of the entire organization. Id. at 517 (Brennan, J., dissenting).

${ }^{27}$ Id. at 507.

${ }^{28}$ Id. at 500. Four justices dissented in Catholic Bishop, accusing the majority of fabricating this "clear statement" canon of construction solely to reach the result it desired. Id. at 511 (Brennan, J., dissenting). The four dissenters argued that the majority's interpretation of congressional intent was entirely improbable, pointing out that in 1974 the Senate had rejected an exception "analogous" to the one created by the majority. Id. at 515 (Brennan, J., dissenting).

29 Id. at 501-04.

so The Court noted that even the NLRB's "completely religious/mere religiously affiliated" dichotomy acknowledged some possibility of entanglement arising from assertion of NLRB jurisdiction over teachers. Id. at 499.

s1 Id. at 501. The Court noted that in prior cases involving federal or state financial aid to parochial schools, "[t]he key role played by teachers in such a school system has been the predicate for our conclusions that governmental aid channeled through teachers creates an impermissible risk of excessive governmental entanglement. . . 'Whether the subject is "remedial reading," "advanced reading," or simply "reading," a teacher remains a teacher, and the danger that religious doctrine will become intertwined with secular instruction persists." " Id., quoting Meek v. Pittenger, 421 U.S. 349, 370 (1975).

${ }^{32} 440$ U.S. at 502 . The majority illustrated this by quoting an exchange between the Rector of one of the schools involved and the NLRB's hearing officer concerning the meaning of "liturgy" and the extent to which the school performed liturgies. Id. at 502 n.10. See the Appendix to the majority opinion in Catholic Bishop, pointing out the difficulty of defining "liturgy" without inquiry into matters of theology. Id. at 507-08. 
Court stated that "[i]t is not only the conclusions that may be reached by the Board which may impinge on rights guaranteed by the Religion Clauses, but also the very process of inquiry leading to findings and conclusions." 3

However, the Court did not go beyond this to specify the precise nature of the first amendment problems that worried it in Catholic Bishop. As a result, the decision has provided little guidance on questions of how much accommodation is mandatory, how much would be permissible, and how much would amount to impermissible establishment when labor laws are applied to particular employment activities of institutions with religious connections. Accordingly, the "difficult and sensitive" questions the Court dodged in Catholic Bishop have refused to disappear. Since 1979, they have resurfaced not only in the context of NLRB jurisdiction over lay teachers employed by parochial schools, but also with regard to the applicability of other labor statutes to other kinds of employees. ${ }^{34}$

\section{The Organizatronal Test}

While Catholic Bishop failed to provide a satisfactory solution to the extent of NLRB jurisdiction over religious institutions, it did identify the appropriate subject of inquiry: whether the nature of the employees' activities is religious or secular. This should have provided a starting point for the courts of appeals' efforts to face these problems. Instead, the courts of appeals have lapsed into the NLRB's fundamental error in Catholic Bishop by concentrating solely on the characteristics of the employer-the religious organization-rather than on the activities of the employees in question. Although these courts have not expressly admitted adopting an organizational test, each of their opinions focuses on the nature of the institution involved and not on the tasks performed by specific employees or classes of employees.

Social welfare organizations affiliated with religious groups are common subjects of analysis. In assessing whether such organizations are secular or religious, the courts of appeals have considered

33 Id. at 502 (footnote omitted).

34 See, e.g., Tony \& Susan Alamo, 471 U.S. 290 (applicability of minimum wage laws to gasoline station workers, hog farmers, candy makers, and a variety of other occupations); Amos v. Corporation of Presiding Bishop, 594 F.Supp. 791, 799 (D. Utah 1984) ("Amos I") (applicability of Title VII to janitors, seamstresses, and typists); Amos v. Corp. of Presiding Bishop of Church, 618 F.Supp. 1013, 1024-27 (D. Utah 1985) ("Amos II") (same), probable jurisdiction noted in both cases, Corp. of Presiding Bishop v. Amos, 107 S.Ct. 396 (1986). 
a variety of factors. The fact that such an organization is operated by a church has not been held dispositive of its status as a religious institution. ${ }^{35}$ Rather, the courts have asked whether the purpose of the organization is religious, ${ }^{36}$ whether the atmosphere within it is predominantly religious, ${ }^{37}$ and whether the activities it performs are "essentially secular." 38 The courts have also looked at the extent to which employees of the organization are hired on the basis of their faith and whether they were expected to propagate religious doctrine at their jobs. ${ }^{38}$

Even church-operated schools have not escaped the appellate courts' inquiry into whether they are predominantly religious or secular. While most decisions have refused to extend NLRB jurisdiction to teachers employed by such institutions, the courts' analysis has always concentrated on the characteristics of the institution rather than on the activities of the employees. ${ }^{40}$ In one of these cases, the First Circuit split 3-3 in its decision and called for Supreme Court guidance as to whether church-operated colleges were exempt from NLRB jurisdiction under Catholic Bishop.11 This plea for guidance appears to acknowledge the appellate courts' failure to identify and agree upon a uniform standard for determining the meaning of "pervasively religious"; in some cases, a factor such as the "promulgation . . . of . . . religious doctrine"42 will be dispositive, for example, whereas in other cases this factor will be ignored. But the First Circuit's formulation of the question to be answered by the Supreme Court also reflects the fatal mistake made by all of the appellate courts in addressing this problem: failure to follow the reasoning of Catholic Bishop by concentrating on the activities of the employees involved.

s5 See, e.g., N.L.R.B. v. St. Louis Christian Home, 663 F.2d 60, 63 (8th Cir. 1981).

${ }^{36}$ See, e.g., Volunteers of America-Minnesota-Bar None Boys Ranch v. N.L.R.B., 752 F.2d 345, 348-49 (8th Cir. 1985); St. Elizabeth Community Hospital v. N.L.R.B., 708 F.2d 1436, 1441 (9th Cir. 1983).

${ }^{37}$ See, e.g., St. Elizabeth Hospital v. N.L.R.B., 715 F.2d 1193, 1196 (7th Cir. 1983); Tressler Lutheran Home for Children v. N.L.R.B., 677 F.2d 302, 305 (3d Cir. 1982).

${ }^{38}$ See, e.g., N.L.R.B. v. Salvation Army of Mass. Dorchester Day Care Center, 763 F.2d 1, 6-7 (1st Cir. 1985); Bar None Boys Ranch, 752 F.2d at 348; St. Louis Christian Home, 663 F.2d at 64 .

39 See, e.g., Volunteers of America, Los Angeles v. N.L.R.B., 777 F.2d 1386, 1390 (9th Cir. 1985); Denver Post, 732 F.2d at 772; St. Louis Christian Home, 663 F.2d at 63.

${ }^{40}$ See, e.g., Universidad Cent. de Bayamon v. N.L.R.B., 793 F.2d 383, 401-03 (1st Cir. 1986); N.L.R.B. v. Bishop Ford Catholic Cent. High Sch., 623 F.2d 818, 822-23 (1980).

41 Bayamon, 793 F.2d at 401.

42 See Denver Post, 732 F.2d at 771. 


\section{The Religion Clauses}

The organizational test adopted by the courts of appeals suffers from several constitutional infirmities. In order to understand the nature and extent of these problems, one must be familiar with the current understanding of the religion clauses of the first amendment.

\section{A. Establishment and Free Exercise}

The first amendment provides that "Congress shall make no law respecting an establishment of religion, or prohibiting the free exercise thereof." 43 The establishment and free exercise clauses of the amendment constitute two distinct limits on permissible government action with respect to religion.

1. Establishment. The chief purpose of the establishment clause is to prohibit government action that favors one religion over another, or religion over non-religion. The modern understanding of the establishment clause's requirements was laid out by the Supreme Court in Lemon v. Kurtzman:44

First, the statute must have a secular legislative purpose; second, its principal or primary effect must be one that neither advances nor inhibits religion. . . Finally, the statute must not foster "an excessive entanglement" with religion. ${ }^{45}$

It is important to note that the Court regards the Lemon test as a "useful," but not "mandatory" test for violations of the religion clauses. ${ }^{46}$

2. Free exercise. The free exercise clause, on the other hand, limits government action that burdens religion. In measuring the demands of the free exercise clause, the Court has drawn a sharp distinction between religious beliefs and religiously motivated conduct. Cantwell v. Connecticut ${ }^{47}$ summarizes the distinction: "[T] [free exercise clause] embraces two concepts-freedom to believe and freedom to act. The first is absolute, but, in the nature of things, the second cannot be. Conduct remains subject to regula-

13 U.S. Const. amend. I. The religion clauses apply to the states through the fourteenth amendment. See Everson v. Board of Education, 330 U.S. 1 (1947) (establishment clause); Cantwell v. Connecticut, 310 U.S. 296 (1940) (free exercise clause).

4403 U.S. 602 (1971).

4s Id. at 612-13.

16 Lynch v. Donnelly, 465 U.S. 668, 679 (1984).

4310 U.S. 296 (1940). 
tion for the protection of society."48 Thus the government may never prohibit or burden religious belief itself; but neutral laws that inhibit conduct mandated by religious beliefs, if justified by "interests of the highest order and those not otherwise served, can overbalance legitimate claims to the free exercise of religion."49

In some cases, a neutral law will place such an onerous burden on religiously motivated conduct that the free exercise clause will require a special exemption for the religious believer in order to accommodate his beliefs. However, the Court has inferred such mandatory exemptions only where there is direct and extreme interference with the religious practices of individuals. For example, in Wisconsin $v$. Yoder, ${ }^{\text {so }}$ the Court found that a state law requiring children to attend public school until age sixteen compelled members of the Amish religion, under threat of criminal prosecution, "to perform acts undeniably at odds with fundamental tenets of their religious beliefs." S1 Similarly, in Sherbert $v$. Verner, ${ }^{52}$ the Court held that a state unemployment commission ruling that one must be "available for work" to qualify for unemployment benefits could not constitutionally apply to a Seventh Day Adventist who refused to work on Saturdays, the sabbath day of her religion. ${ }^{53}$ The Court found that the disqualification forced the religious adherent to choose between the precepts of her religion and civil law. ${ }^{\text {.4 }}$

In United States $v$. Lee, ${ }^{, 5}$ however, the Court placed an important limit on the logic of Sherbert and Yoder. The Court in Lee held that the broad public interest in maintaining a sound Social Security system was so vital that the Amish beliefs forbidding payment of Social Security tax offered no basis for resisting the tax. The Court argued that allowing religiously motivated exemptions would significantly impair the "fiscal vitality of the social security

4s Id. at 303-04, citing Reynolds v. United States, 98 U.S. 145 (1878), and Davis v. Beason, 133 U.S. 333 (1890).

40 Wisconsin v. Yoder, 406 U.S. 205, 215 (1972). See also Braunfeld v. Brown, 366 U.S. 599,603 (1961) (freedom to act may be reasonably restricted by neutral legislation); Reynolds, 98 U.S. at 166 (same).

so 406 U.S. 205 (1972).

82 Id. at 218.

32 U.S. 398 (1963).

ss Id. at 410 .

s4 Id. at 404. See also Thomas v. Review Bd., Ind. Empl. Sec. Div., 450 U.S. 707 (1981) (state may not deny unemployment benefits to Jehovah's Witness who left his job because of religious belief when he was transferred to a job producing munitions).

ss 455 U.S. 252 (1982). 
system"se and added:

When followers of a particular sect enter into commercial activity as a matter of choice, the limits they accept on their own conduct as a matter of conscience and faith are not to be superimposed on the statutory schemes which are binding on others in that activity. ${ }^{.7}$

Thus the Court in Lee was reluctant to allow an exemption from a neutral law for a religious group when that group chose to engage in commercial activity that was not a matter of necessity.

Finally, even where a government regulation significantly interferes with sincere religiously motivated conduct, the burden may be justified by a compelling state interest. For example, in Bob Jones University $v$. United States, ${ }^{58}$ the Court upheld an IRS denial of tax benefits to a university that had a religiously based policy of racial discrimination. The Court recognized that denial of tax benefits would have a "substantial impact" on the operation of such religious schools, but it held that imposition of this burden was justified by the government's interest in eradicating racial discrimination. ${ }^{58}$ And in any event, the Court reasoned, denial of tax exemption would not prevent the university from following its religious beliefs; it would only prevent it from enjoying an exemption from otherwise applicable government regulations while indulging in action based on beliefs contrary to the compelling state interest in eradicating racial discrimination..$^{60}$

\section{B. The Tension Between Establishment and Accommodation}

Both courts and commentators have often noted the fundamental tension between the establishment and free exercise clauses. ${ }^{61}$ In some cases, the protection of the free exercise clause

so Id. at $260-61$.

${ }^{37}$ Id. at 261.

ss 461 U.S. 574 (1983).

B9 Id. at 603-04. Consider also Bowen v. Roy, 106 S.Ct. 2147 (1986), where, in denying a claimed free exercise exemption from taking a social security number, the Court said: "Absent proof of an intent to discriminate against particular religious beliefs or against religion in general, the Government meets its burden when it demonstrates that a challenged requirement for government benefits, neutral and uniform in its application, is a reasonable means of promoting a legitimate public interest." Bowen, $106 \mathrm{S.Ct}$. at 2156.

${ }^{\circ 0}$ Bowen, 106 S.Ct. at 2156. See also Tony \& Susan Alamo, 471 U.S. at 303: "It is virtually self-evident that the Free Exercise Clause does not require an exemption from a governmental program unless, at a minimum, inclusion in the program actually burdens the claimant's freedom to exercise religious rights."

- On the tension between the two clauses, see Thomas, 450 U.S. at 719-20; id. at 720 
extends beyond mere prohibition of state action directed against religion; the clause may confer a positive right upon adherents to be exempt from laws of general applicability. ${ }^{62}$ Such constitutionally mandated accommodation appears to shade into establishment on all three counts set out in Lemon. First, the purpose of accommodation is, by definition, nonsecular. Second, by exempting religious adherents from laws that govern nonadherents, the practice of accommodation favors religion generally, and each particular exemption favors the particular faith of those exempt. Third, accommodation requires that some government body-legislatures or the courts-decide whose religious beliefs should be accommodated, by how much, and in what circumstances. This necessarily involves the government in matters of theology: it must decide what beliefs merit being considered "religious" and thus merit accommodation. The result may be impermissible entanglement under Lemon. ${ }^{63}$

Of course, to the extent that accommodation is required by the free exercise clause, it does not run afoul of the establishment clause. ${ }^{64}$ But to go beyond required accommodation may constitute

(Rehnquist, J., dissenting); Wallace v. Jaffree, 472 U.S. 38, 81-83 (1985) (O'Connor, J., concurring); Sherbert, 374 U.S. at 414 (Stewart, J., concurring); Gerald Gunther, Cases and Materials on Constitutional Law 1546 (10th ed. 1980); Comment, Equal Employment or Excessive Entanglement? The Application of Employment Discrimination Statutes to Religiously Affiliated Organizations, 18 Conn. L. Rev. 581, 589 (1986).

${ }^{62}$ See, e.g., Yoder, 406 U.S. at 220: "A regulation neutral on its face may, in its application, nonetheless offend the constitutional requirement for governmental neutrality if it unduly burdens the free exercise of religion."

${ }^{63}$ In Bob Jones University, 461 U.S. at 604 n.30, the Court recognized such an inquiry as "potentially entangling." The decision as to what organizations should receive exemptions based on their religious character also raises the danger of "political divisiveness" that the Court has identified as a concern of the entanglement prong of Lemon. See 403 U.S. at 622.

Of course, an exemption from regulation also reduces church-state entanglement, since regulation involves supervision and other contact. See Walz v. Tax Commission, 397 U.S. 664, 674 (1970) (elimination of tax exemptions for church property would tend to expand government involvement with religion). However, there must be some limitation on this principle, because otherwise it could be used to justify exemption from all regulation. For examples of cases in which the Court has recognized limitations, see Lee, 455 U.S. at 259 (holding that precisely because it would be difficult to accommodate the comprehensive social security system with myriad exemptions granted to a wide variety of religions, the Amish could not be exempted from paying social security taxes); Tony \& Susan Alamo, 471 U.S. at 305-06 (holding that application to a religious organization of the record keeping requirements of the Fair Labor Standards Act did not result in sufficient entanglement to warrant complete exemption from the statute, and pointing out that the free exercise clause does not exempt religious organizations from secular governmental regulations such as building and fire codes).

64 In Jaffree, Justice O'Connor suggested in a concurrence that the "government pursues free exercise clause values when it lifts a government-imposed burden on the free exercise of religion." 472 U.S. at 83 . She argues that accommodation of religion is permissible 
an establishment of religion. ${ }^{65}$ Many commentators have explored the boundary between accommodation compelled by the free exercise clause and the benefit to religion prohibited by the establishment clause. All agree that accommodation of free exercise rights must at some point shade into impermissible establishment, while acknowledging that there is disagreement about the precise point at which this occurs. ${ }^{66}$ Professor Michael McConnell suggests that the courts are confined to inferring free exercise exceptions to laws only when accommodation is "mandatory," whereas the legislature has some discretion to go further into "permissible accommodation" before an exemption shades into impermissible establishment. ${ }^{67}$

\section{The Flaws of the Organizational Test}

\section{A. Constitutional Infirmities}

Because of its use of the "clear statement" canon of construction, the Supreme Court found it unnecessary in Catholic Bishop to elaborate on the constitutional problems caused by the NLRB's organizational approach to accommodation. The adoption by the courts of appeals of a similar organization-based approach, set against the background of employee-based accommodation under section 19, compels more detailed examination of the constitutional issues. By attempting to solve the first amendment problems identified in Catholic Bishop through a blanket exemption for "pervasively religious" organizations, the courts of appeals have run afoul of the religion clauses in three distinct ways.

while endorsement, barred by the establishment clause, is not. Id. at 69-70. Consequently, " $[t]$ he solution to the conflict between the Religion Clauses lies not in 'neutrality,' but rather in identifying workable limits to the government's license to promote the free exercise of religion." Id. at 83.

is Id. at 84 (O'Connor, J., concurring). This tension between the clauses predates the Lemon test for establishment. Justice Stewart noted the conflict in 1963: "there are many situations where legitimate claims under the Free Exercise Clause will run into head-on collision with ... the Establishment Clause." Sherbert, 374 U.S. at 414 (Stewart, J., concurring).

ss See, e.g., Michael W. McConnell, Accommodation of Religion, 1985 S. Ct. Rev. 1, 3441; Douglas Laycock, Towards a General Theory of the Religion Clauses: The Case of Church Labor Relations and the Right to Church Autonomy, 81 Colum. L. Rev. 1373, 137888 (1981); Philip B. Kurland, The Irrelevance of the Constitution: The Religion Clauses of the First Amendment and the Supreme Court, 24 Vill. L. Rev. 3, 24 (1978); Gail Merel, The Protection of Individual Choice: A Consistent Understanding of Religion Under the First Amendment, 45 U. Chi. L. Rev. 805, 809-15 (1978); Philip B. Kurland, Religion and the Law 18 (1962).

62 McConnell, 1985 S. Ct. Rev. at 29-34 (cited in note 66). 
1. Cverinclusiveness. When an organization is classified as "pervasively religious" under the organizational test, all of its employees, including those engaged in secular activities that would otherwise fall within the purview of the NLRA, are excluded from NLRB jurisdiction. This goes beyond the bounds of permissible, let alone mandatory, accommodation and constitutes establishment of religion.

Courts have divided on whether any secular purpose is served by the courts of appeals' creation of a blanket exemption from NLRB jurisdiction for all religiously affiliated educational institutions. ${ }^{68}$ More importantly, however, the organizational test has the primary effect of advancing religion. It gives religious organizations an advantage over other employers by exempting the organizations from labor regulations; and it does so even in the organizations' nonreligious employment activities where no significant rights of religious exercise are at stake.

Several courts have suggested that a blanket exemption from labor laws for all religious institutions violates the establishment clause by impermissibly aiding religion. In King's Garden, Inc. v. F.C.C., ${ }^{69}$ the District of Columbia Circuit considered the constitutionality of section 702 of Title VII, ${ }^{70}$ which exempts religious organizations' hiring on the basis of religion in all of their employment activities, religious or secular. In strongly worded dictum, the court concluded that the exemption impermissibly had the direct and immediate effect of advancing religion: "[it] invites religious groups, and them alone, to impress a test of faith on job categories, and indeed whole enterprises, having nothing to do with the exercise of religion."71 The court noted that while establishment clause cases typically involve government subsidies or tax breaks for religious groups, the framers were equally concerned with "non-financial" sponsorship of religion. ${ }^{72}$ The court thus concluded that the blanket exemption under Title VII was equivalent to sponsor-

${ }^{68}$ For a similar argument with regard to the Title VII blanket exemption, see King's Garden, Inc. v. F.C.C., 498 F.2d 51, 55 (D.C. Cir. 1974).

69 Id.

70 Section 702 provides:

This subchapter shall not apply to . . . a religious corporation, association, educational institution, or society with respect to the employment of individuals of a particular religion to perform work connected with the carrying on by such corporation, association, educational institution, or society of its activities.

42 U.S.C. $\S 2000 \mathrm{e}-1$ (1982).

${ }^{71}$ King's Garden, 498 F.2d at 55.

72 Id. 
ship:73 "It is a sure formula for concentrating and vastly extending the worldly influence of those religious sects having the wealth and inclination to buy up pieces of the secular economy.""74

The King's Garden analysis was followed recently in Amos $v$. Corporation of Presiding Bishop (Amos $I),{ }^{75}$ in which a federal district court held that the Title VII exemption for religious organizations is unconstitutional as applied to "secular, non-religious activities." ${ }^{\text {" }}$ The Amos I court also noted, following Supreme Court precedents, that the organizational exemption can violate the establishment clause simply by creating the potential for impermissible fostering of religion: "Congress cannot provide a federal exception for religious organizations based on an assumption that religious organizations will avoid using section 702 to further religious beliefs." "77

The King's Garden-Amos $I$ analysis is convincing in light of the framers' intentions. An exemption of religion from its civil obligations was precisely what underlay Locke's and Jefferson's fears that a religious institution might establish itself as a national religion. ${ }^{78}$ The history of the first amendment compels the conclusion that at times the state must assert its interest in regulating the secular employment activities of religious organizations.

If granting a blanket exemption from Title VII to a religious organization violates the establishment clause, so must a blanket exemption from the NLRA. There is no significant functional difference in the extent or manner that the NLRA and Title VII affect religious organizations. Both statutes significantly constrain employers' behavior. ${ }^{79}$ The EEOC's potential jurisdiction in this

${ }^{73}$ Id.

74 Id. (footnote omitted).

76594 F.Supp. 791 (D. Utah 1984), probable jurisdiction noted, 107 S. Ct. 396 (1986).

76 Amos I, 594 F.Supp. at 825. See also Feldstein v. Christian Science Monitor, 555 F.Supp. 974 (D. Mass. 1983).

77 See Amos I, 594 F.Supp. at 827, citing Lemon, 403 U.S. at 619.

73 See John Locke, A Letter Concerning Toleration, in Maurice Cranston, ed., Locke on Politics, Religion and Education 104-46 (1965); S. Gerald Sandler, Lockean Ideas in Jefferson's Bill for Establishing Religious Freedom, 21 J. Hist. Ideas 110 (1960).

70 For example, the EEOC is authorized to inquire into various types of evidence: comparative evidence, statistical evidence, and direct evidence of discriminatory motive. 2 EEOC Compliance Manual $\S 602.5$ (CCH ed. 1980 \& Supp. 1986). Similarly, the NLRB is authorized to issue subpoenas "requiring the attendance and testimony of witnesses and the production of any evidence, including books, records, correspondence, or documents, in their possession or under their control." 29 C.F.R. $\$ 102.31$ (1986). Additionally, the EEOC may grant temporary and permanent injunctive relief. 42 U.S.C. $\$ \S 2000 \mathrm{e}-5(\mathrm{f}), 2000 \mathrm{e}-5(\mathrm{~g})$. Likewise, the NLRB may temporarily enjoin employers from unfair labor practices. 29 U.S.C. $\S 160(\mathrm{e})$. 
context is at least as intrusive as the NLRB's. While NLRB regulation might be viewed as ongoing in that the NLRB occasionally might need to conduct repeated analyses of employee functions to determine the breadth of its jurisdiction, the EEOC's permanent injunctive powers could also establish an ongoing relationship between church and state. Once the EEOC has issued a permanent injunction, it continually restrains the employer from discriminatory practices. ${ }^{80}$

Moreover, although the Title VII exemption itself violates the establishment clause, that exemption does have one justification that the blanket organizational exemption from the NLRA lacks: the Title VII exemption reflects a considered congressional judgment as to how far to accommodate religion. As the Court noted in upholding tax exemptions for church property in Walz v. Tax Commission: ${ }^{\mathbf{3 1}}$

Short of those expressly proscribed governmental acts there is room for play in the joints productive of a benevolent neutrality which will permit religious exercise to exist without sponsorship and without interference. . . . The limits of permissible state accommodation to religion are by no means coextensive with the noninterference mandated by the Free Exercise Clause. ${ }^{82}$

Citing Walz, Professor McConnell has argued that a legislative accommodation should be upheld if the religious individual or institution can simply make out a "prima facie" free exercise claim to the accommodation, while courts should only create exemptions after a considered finding that the free exercise clause truly compels the accommodation. ${ }^{83}$ This is because the legislature is in the best position to determine whether it can grant an exemption "without unacceptable damage to its policies." Title VII exemption might be defended as a congressional judgment that this accommodation of religious exercise can be pursued without substantial harm to the statute's goals, the judicially cre-

so In fact, even without its section 702 blanket exemption, Title VII would be more intrusive than the NLRA. The EEOC has the authority to act with regard to prospective employees who have alleged discrimination in hiring practices. 42 U.S.C. $\$ 2000 \mathrm{e}-2(\mathrm{a})(1)$. Since the NLRB can act only with regard to already hired employees, 29 U.S.C. § 152(3), in this regard at least Title VII is more intrusive.

s1 397 U.S. 664 (1970).

${ }^{82}$ Id. at $669,673$.

3s McConnell, 1985 S. Ct. Rev. at 31 (cited in note 66).

st. 
ated organizational exemption from the NLRA is entitled to no such deference. Whatever the constitutionality of the Title VII statutory exemption, the judicially created organizational test is unconstitutional.

The overinclusiveness of the organizational exemption stands in sharp contrast to the permissible accommodation of religion under section 19 of the NLRA, which allows individual employees to substitute equal payments to a charity for union dues. Such an accommodation serves only to keep individual religious adherents at the same social or economic level as their nonreligious peers, rather than affording one or the other an advantage. This sort of employee-based accommodation has consistently been held constitutionally permissible, ${ }^{85}$ in contrast to accommodations like the organizational test, which bestows an advantage rather than just eliminating a burden.

2. Underinclusiveness. The organizational test may produce underinclusive accommodation when the character of the organization is adjudged to be secular, because in such cases employees in truly religious activities are also covered by the labor regulatory statute in question. ${ }^{86}$ This may violate the free exercise rights of individual employees or the organization.

In addressing a free exercise question, a court must first determine whether a religiously based action poses a threat to the public order and whether the state's restriction of that action would burden free exercise rights. If the court determines that the state's restriction is a burden, then the religious believer or institution must be exempted unless the state can assert a compelling interest that would be frustrated by the exemption. ${ }^{87}$

The organizational approach to exemption fails to comport with these standards. As the Seventh Circuit recognized in rejecting the NLRB's organizational test in Catholic Bishop, the organizational approach sometimes encompasses a great many religious activities within an organization simply because the organization as a whole cannot be said to be "completely" or "pervasively" religious. ${ }^{88}$

In particular, the organizational test conflicts with the courts'

ss See, e.g., Tooley v. Martin-Marietta Corp., 648 F.2d 1239, 1244 (9th Cir. 1981).

${ }^{86}$ In the case of the NLRA, section 19 provides a safety valve that helps to mitigate the Act's impact on free exercise rights. However, no such provision is available in the case of other statutes like the Fair Labor Standards Act, 29 U.S.C. \$§ 201-19 (1982).

87 See notes $49,55-60$ and accompanying text above.

so Catholic Bishop, 559 F.2d at 1118. See text at note 25 above. 
consistent holdings that the free exercise clause requires exemptions from Title VII and the NLRA for ministers and other employees performing core religious functions. ${ }^{88}$ The courts also have consistently determined that such a limited exemption does not frustrate the compelling interests behind the labor statutes. ${ }^{90}$ But under the organization-based approach to exemption, if an organization is deemed pervasively secular, the court will allow all of its employees-including ministers and core religious functionaries-to be subject to the NLRA. This result does not even permit a minister, if employed by a "secular" organization, her free exercise right to choose to abide solely by the decisions of the the religious organization; contrary union rules may govern her decision.

3. Impermissible entanglement in questions of theology. Under the organizational test, the courts must determine whether the institution's character is "pervasively religious." This inquiry is too intrusive and itself violates the establishment clause. The state ultimately attempts to decide whether a religion exists, or is being practiced, with regard to the institution over which the NLRB has asserted jurisdiction. Inevitably the state must become involved in answering theological questions: When is there a propagation of faith such that an organization is "pervasively" religious? What type of organization is "religious"? When is the purpose or function of an activity "religious"? To have the state answer these questions necessarily entangles it impermissibly in theological debates. The Court has repeatedly recognized that such an inquiry is "potentially entangling."

The potential scope of organizations and activities that may be characterized as "religious" is very broad;" it is both practically difficult and constitutionally problematic for courts to make such an inquiry. Evaluating theologies to determine which wins an exemption from the labor laws is both intrusive and entangling and thus clearly problematic under the entanglement prong of the

89 See, e.g., McClure v. Salvation Army, 460 F.2d 553 (5th Cir. 1972) (ministerial exemption from Title VII); EEOC v. Southwestern Baptist Theological Seminary, 651 F.2d 277, 284-85 (5th Cir. 1981) (exemption from Title VII for upper administrative staff of seminary, because these considered "ministers").

so See, e.g., McClure, 460 F.2d at 558-60.

91 Bob Jones University, 461 U.S. at 604 n.30, citing Gillette v. United States, 401 U.S. 437, 458 (1971) (upholding draft exemption limited to conscientious objectors who opposed all wars, on ground that judicial extension of exemption to religious objectors who opposed only a particular war would "entangle government in difficult classifications of what is or is not religious").

82 See, e.g., Tony \& Susan Alamo, 471 U.S. at 298-99 (religious organization claims that its profitmaking farming and manufacturing were "religious" activities). 
Lemon test. The entanglement of government in matters of religion is still problematic when it is the courts, not the NLRB, that do most of the evaluating.

Of course, in some situations inquiry into what is a "religious" belief, practice, or institution may be inevitable..$^{93}$ For example, in the line of school aid cases beginning with Lemon, the Court has first determined whether the schools receiving state aid are "pervasively religious"; this first step is crucial in the ultimate determination of whether the provision of aid violates the establishment clause. ${ }^{94}$ In many of these cases, however, it is impossible to avoid asking about the religious nature of the institution, since it is the institution receiving the funds. ${ }^{95} \mathrm{By}$ contrast, in the context of labor regulation, analyzing exemptions by reference to employees' activities is a superior way of resolving the constitutional issue of exemptions without extensive inquiry into an institution's beliefs and theology. Such an approach minimizes the inquiry and is far preferable to one such as the organizational test, which involves extensive and unnecessary examination.

\section{B. The Organizational Test Conflicts With Section 19}

In addition to being constitutionally flawed, the organizational

9s For example, the inquiry is obviously necessary in free exercise cases, since a belief or practice must qualify as "religious" in order to receive the clause's protection. See Thomas, 450 U.S. at 713-14 ("[o]nly beliefs rooted in religion are protected by the Free Exercise Clause").

94 Contrast, e.g., Lemon, 403 U.S. at 615-18 (striking down aid to teachers in parochial schools where schools involved "substantial religious activity and purpose"); Grand Rapids School Dist. v. Ball, 473 U.S. 373, 105 S.Ct. 3216, 3223 (1985) (striking down government funding of supplementary courses to students in "pervasively sectarian" schools); Aguilar v. Felton, 105 S.Ct. 3232, 3238 (1985) (same), with Tilton v. Richardson, 403 U.S. 672 (1971), and Roemer v. Maryland Public Works Board, 426 U.S. 736, 758-59 (1976) (both upholding provision of aid to colleges that, although religiously affiliated, were not "pervasively sectarian").

The distinction is virtually dispositive because with "pervasively religious" institutions, the Court assumes that aid to the institution will be likely to advance religion, and that government scrutiny to prevent this result will have to be so intrusive that it will constitute excessive entanglement. See, e.g., Aguilar, 105 S.Ct. at 3237-38; Lemon, 403 U.S. at 619. With institutions that are not pervasively sectarian, however, the Court assumes no overly intrusive scrutiny will be required. Aguilar, 105 S.Ct. at 3237-38.

os Where this is the case, courts usually have little difficulty identifying an establishment of religion. See, e.g., Meek v. Pittenger, 421 U.S. 349, 354 (1975) (direct aid to religious schools in the form of instructional materials and equipment held unconstitutional); Committee for Public Education v. Nyquist, 413 U.S. 756 (1973) (holding that direct cash grants to nonpublic schools for "maintenance and repair" are unconstitutional); Levitt v. Committee for Public Education, 413 U.S. 472, 474 (1973) (direct aid in the form of money intended to be used for standardized testing materials held unconstitutional). 
test adopted by the appellate courts operates at cross purposes with section 19 of the NLRA. The organizational test requires the NLRB to determine the character of the organization; but in many cases, a wholly separate inquiry will be required under section 19 to decide the free exercise claims of individual employees who seek exemption from the labor statutes. It is extremely likely that any given case will involve both inquiries; religious organizations have standing to raise free exercise claims on behalf of their employees, ${ }^{96}$ and it is difficult to imagine why such organizations would ever fail to do so. Thus, the organizational test often requires an inquiry into the employee's activity, but it also mandates characterization of the organization. It offers no real advantage in return for this added administrative complexity.

This combination of organizational and employee-based inquiries will work well only if both inquiries address distinct problems and if those doing the inquiring understand the distinction. In the context of NLRA exemption, there is reason to be skeptical that the Board will be able to separate the two inquiries. While the concerns behind section 19's accommodation of individual employee's free exercise rights are clear and defensible, those behind the organizational test have not been defined clearly either in Catholic Bishop or in the courts of appeals. In this confusion, the finding that an organization is or is not "pervasively religious" may color the inquiry into the sincerity of individual beliefs behind the section 19 exemption.

\section{A Proposed Solution: The Employee Activity Test}

The NLRB and the courts should focus on the activities of the specific employees in question in a labor dispute rather than on the nature of the organization. This much is clear from a careful reading of Catholic Bishop. But how should such an inquiry be conducted, bearing in mind both the need to prevent religious organizations from encouraging public officials to violate the establishment clause and the need to accommodate free exercise rights? And how can any such inquiry avoid the potential for entanglement that the majority of the Court feared in Catholic Bishop?

This comment proposes a two-step test for resolving whether employee activities in religious organizations should be subject to labor statutes such as the NLRA, Title VII, and the Fair Labor Standards Act. First, courts should ask whether the employees in

${ }^{96}$ Tony \& Susan Alamo, 471 U.S. at 303 n.26. 
question were hired through solicitation of the general public. If the religious organization has behaved just like any other employer that bids for employees in the secular marketplace, then it is appropriate for it to comply with fair labor practice regulations.

Second, courts should examine whether the functions that the employee or employees perform can be distinguished from profitmaking activities ordinarily performed in secular settings only by reference to the particular theological tenets of the religious organization. If resort to the religion's particular theology is necessary to draw such a distinction, a reasonable conclusion is that the religious organization is attempting to impose its particular view of "religion" on the government. This would constitute impermissible entanglement in violation of the establishment clause.

Both prongs of the employee activity test are designed to uncover evidence of the secular nature of the job in question. Therefore, an affirmative answer at each step of this proposed "employee activity test" is a sufficient, but not necessary, condition for the exercise of NLRB jurisdiction. A strong showing on either inquiry will be allowed to compensate for a weak or nonexistent showing with regard to the other. This is consistent with the Court's rejection of approaches that purport to set "the precise limits to the necessary constitutional inquiry" and its preference for flexible "guidelines with which to identify instances in which the objectives of the establishment clause have been impaired."

Because the purpose of the test is to uncover evidence of the secular nature of the job, if such evidence exists, the second prong of the test is more fundamental than the first. The manner in which the employment relationship arose may provide valuable, and sometimes even dispositive, evidence of the secular nature of the job: if an employee was hired exclusively through recourse to non-public channels of information open only to communicants, a strong showing that the job is indistinguishable from secular activities would be required to subject that employee to the jurisdiction of the labor statutes. However, where the two tests are in equipoise-that is, where the employee was hired privately but is performing clearly indistinguishable functions-the more fundamental inquiry under the second prong of the test would be dispositive.

Significantly, in cases raising issues of accommodation under Title VII and the Fair Labor Standards Act, the courts actually 
have used a variation of the employee activity test. ${ }^{98}$ Having decided that only the church-minister relationship is excluded from coverage under such statutes, the courts have assessed the activities of the employees in question to determine whether they perform a minister-like function. If the employee does not perform such a religious function, the courts have held that the statutes must be extended to cover such employees to avoid violation of the establishment clause.

The particularized inquiry into the nature of the employee's activity is more appropriate than the organizational test for two reasons. First, it avoids both the overinclusiveness and underinclusiveness of the organizational approach by distinguishing between the secular employment activities of religious institutions, which do not require accommodation, and employment in religious activities, in which accommodation of belief is mandatory. Second, the employee activity test frames the accommodation inquiry in terms that are less intrusive to the organization and that pose a lesser threat of government entanglement in theological debates than the organizational test's needlessly broad inquiry into an employer's "religious" character. The remainder of this section discusses these advantages as it explains how the employee activity test would work in practice.

\section{A. The Test Avoids Overinclusive Accommodation}

The organizational approach to accommodation grants religious organizations blanket exemption from NLRA jurisdiction; as argued above, this constitutes establishment of religion. The employee activity test, by contrast, does not step over into establishment: it holds the religious organization to its secular civil obligations with respect to employees performing secular functions. The employee-based inquiry thus prevents the religious organization from imposing its political or religious beliefs on its employees and on the state.

${ }^{88}$ In McClure, 460 F.2d 553, the Fifth Circuit held that the application of Title VII to Salvation Army ministers would violate the religious group's free exercise rights. This was based on the reasoning that the "relationship between an organized church and its ministers is its lifeblood." Id. at 558. The Fifth Circuit has also created an analogous exemption for faculty and administration at a seminary, finding these positions to be ministerial. Southwestern Baptist Seminary, 651 F.2d 277. But in E.E.O.C. v. Mississippi College, 626 F.2d 477, 488 (5th Cir. 1980), the same court held that the exemption did not apply beyond church-minister relations. See also E.E.O.C. v. Pacific Press, 676 F.2d 1272 (9th Cir. 1981) (permitting application of Title VII to an employee who performed editorial and secretarial functions for a nonprofit religious publishing house). 


\section{B. The Test Avoids Underinclusive Accommodation}

Unlike the organizational test, the employee activity test prevents NLRB jurisdiction from extending to employees performing religious functions in largely secular organizations. This protects the free exercise rights of both the individual employees and the organizations.

On the other hand, the employee activity test, unlike the organizational test, requires religious organizations to comply with the NLRA in their secular employment activities. Admittedly, this extension of jurisdiction might have a considerable impact on such organizations. The imposition of bargaining procedures and unfair labor practice grievance channels would alter the present employer-employee arrangements existing in religiously affiliated schools, and in those religiously affiliated hospitals and social service agencies to which courts of appeals have granted blanket exemptions under the organizational test.

Nevertheless, the free exercise clause does not require that religious organizations receive a blanket exemption for their secular as well as religious activities. Such exemptions from neutral laws are compelled only in rare circumstances ${ }^{99}$ where the effect on exercise of religious beliefs is severe and where granting the exemption would not frustrate the government's achievement of the compelling state interest underlying the law. ${ }^{100}$ The exemption for secular employment activities fails to qualify under any of these criteria.

1. Burden on religious beliefs. It may well be, as noted above, that application of the NLRA to religious organizations' secular employment activities would have a significant effect on those organizations. But this is irrelevant: the pertinent free exercise inquiry "is not the impact of the statute upon the institution, but the impact of the statute upon the institution's exercise of its

"9 In only three cases has the Court ever granted such an exemption. Thomas, 450 U.S. at 717-18; Yoder, 406 U.S. at 218-19; Sherbert, 374 U.S. at 404-06. In contrast, see Lee, 455 U.S. at 256-60.

${ }^{100}$ Mississippi College, 626 F.2d at 488. The Fifth Circuit in this case assembled a three part test, which is applied below, for determining whether a statutory enactment unconstitutionally interferes with the free exercise of a sincerely held religious belief, so as to require an exemption for the religious practice. The test considers the magnitude of the statute's impact upon the religious practice, the existence of a compelling state interest, and the extent to which an exemption from the challenged statute would impede its objectives. See Comment, 18 Conn. L. Rev. at 595 (cited in note 61). See also notes $49-60$ and accompanying text above. 
sincerely held religious beliefs." 101

Providing coverage under the NLRA for employees engaged in secular functions would not have an impact on "sincerely held religious beliefs"102 sufficient to compel exemption. The Court has held that only a burden that forces an individual or institution to choose between religion and civil law can preclude the state from asserting a compelling interest. ${ }^{103}$ No church seeking to escape NLRB regulation has argued that it faces such a choice. Whatever effect NLRB jurisdiction would have on religious beliefs (as opposed to religious organizations) would be relatively minor. The statutory powers of the NLRB, applied to the secular activities of religious organizations, do not permit the Board to infringe on the free exercise right to make decisions of a religious nature.

With regard to bargaining procedures, the NLRA merely requires employers and unions to bargain in good faith about wages, hours, and other terms and conditions of employment, and to incorporate any agreement reached in writing. ${ }^{104}$ The employer is not required either to concur in the unions' demands or even to reach any agreement whatever. ${ }^{105}$ Since 1947 , the same principle has been incorporated in the language of section $8(\mathrm{~d})$ of the NLRA. ${ }^{108}$ Thus, even as to those subjects over which an employer is obligated to bargain in good faith, an employer may refuse to agree with the union for economic or other reasons-including reasons relating to its own religious views.

In situations where the NLRA commands inquiry into specific unfair labor practices, such inquiries can be made without producing entanglement in religious doctrine. In most NLRA cases, particularly those brought under sections $8(a)(1)$ and $8(a)(3),{ }^{107}$ the

${ }^{101}$ Mississippi College, 626 F.2d at 488.

102 Id.

${ }^{103}$ See notes 53-57 and accompanying text above.

10429 U.S.C. § $158($ d). See also Labor Board v. Jones \& Laughlin, 301 U.S. 1, 45-46 (1937):

The Act does not interfere with the normal exercise of the right of the employer to select its employees or to discharge them. The employer may not, under cover of that right, intimidate or coerce its employees with respect to their self-organization and representation, and, on the other hand, the Board is not entitled to make its authority a pretext for interference with the right of discharge when that right is exercised for other reasons than such intimidation and coercion. The true purpose is the subject of investigation with full opportunity to show the facts.

${ }_{105} 29$ U.S.C. § 158(d). See also Jones \& Laughlin, 301 U.S. at 45 (constitutionality of Act is dependent on fact that Act provides voluntary and not compelled opportunity for negotiation).

${ }^{106} 29$ U.S.C. $\$ 158(\mathrm{~d})$.

${ }^{107}$ Id. $\$ \S 158(a)(1), 158(a)(3)$. 
decision turns on the intent of the employer. ${ }^{108}$ While both the Seventh Circuit and the Supreme Court in Catholic Bishop apparently recognized that a showing of anti-union animus is ordinarily a prerequisite to finding an unfair labor practice under these sections, they evidently believed that the very act of establishing such a motive could lead to excessive intrusion into religious beliefs. But this overlooks the fact that there are several types of inquiry into religious motivation. First, there is inquiry into whether the reason given motivated the action taken. Second, there is inquiry into whether the religious reason given actually reflects the precepts of the church involved. Finally, there is inquiry into the validity of the religious precept as a matter of abstract truth. Many of these inquiries will avoid the problematic examination of religious doctrine that plagues the organizational test.

For example, in Catholic Bishop the Seventh Circuit posited a situation in which a teacher involved in pro-union activity and also in activity contrary to church doctrine is discharged. It then simply asserted that any unfair labor practice proceeding in such a case would involve the Board in doctrinal matters. ${ }^{109}$ This statement, read narrowly, is undoubtedly true: the church-affiliated school, like any other employer, would be entitled to offer proof that the reason for the discharge was not union activity but an entirely unrelated factor-breaking a work rule or, in this instance, failing to abide by religious rules, observance of which is required of all teachers. Whether the reason claimed by the employee or that claimed by the employer actually motivated the discharge would then be at issue, and to that degree the church's religious precepts would be "involved." But, as the broad outline of the methodology in unfair labor practice cases suggests, this kind of question can be

108 Thus, when the employer discharges a union leader who has broken shop rules, the problem posed is to determine whether the employer has acted purely in disinterested defense of shop discipline or has sought to damage employee organization. It is likely that the discharge will tend to discourage union membership in both cases, because of the loss of union leadership and the employees' suspicion of the employer's true intention. But $\S 8(a)(3)$ has consistently been construed to leave unscathed a wide range of employer actions taken to serve legitimate business interests in some significant fashion, even though the act committed may tend to discourage union membership. N.L.R.B. v. Mackay Co., 304 U.S. 333, 345 (1938). This interpretation of $\S 8(\mathrm{a})(3)$ is essential if true protection is to be accorded to the employer's right to manage his enterprise. Textile Workers v. Darlington Co., 380 U.S. 263, 269 (1965).

It is true that in some cases, where the employer's conduct involved is inherently prejudicial and devoid of economic justification, no specific evidence of intent to discourage union membership, or of other anti-union animus, is required. Radio Officers v. Labor Board, 347 U.S. 17, 44-52 (1954); Labor Board v. Erie Resistor Corp., 373 U.S. 221, 227 (1963).

${ }^{109}$ Catholic Bishop, 559 F.2d at 1125. 
adjudicated-and in industrial conflicts usually is adjudicated-by means which do not in any real sense implicate the second line of inquiry described above, and which never involve the third at all.

For example, the first and simplest line of inquiry is whether the employee discharged actually espoused the antireligious view or committed the antireligious act claimed; if so, whether the employer stated those views or acts as the reason for the discharge when it occurred; and whether the employee was in fact known by the employer to be a union activist. If these facts were established, the employee might show that the "heretical" views or lifestyle claimed as the reason for the discharge had been known to the employer for an extended period, but were acted upon only when union activity began. Similarly, he might attempt to demonstrate that among those employees who espoused "heretical" views, only union activists were discharged. If either of these facts were proven, a finding of impermissible motive could easily follow without further inquiry. ${ }^{110}$ Conversely, the employer might be able to show that whenever the "heretical" views or lifestyle of a teacher came to its attention, that teacher was fired forthwith-regardless of his views on labor unions.

Thus, it would ordinarily be possible to resolve the decisive question of motivation with reference to empirical, secular facts. If the employer succeeded in showing in this manner that his claimed motivation was the true one, it would be entirely irrelevant whether the rule enforced derived from the employer's notion of good religion, good manners, or good economics, as long as antiunion animus was ruled out as a contributing factor. ${ }^{111}$ This sort of adjudication under the NLRA-which existed even before section 19-does not violate the free exercise clause because it does not burden religious beliefs, although it may burden religious organizations.

2. Compelling state interest. Even if the NLRB's exercise of jurisdiction did burden the sincerely held religious beliefs of an organization, the existence of a compelling state interest justifies the

110 See American Ship Bldg. v. Labor Board, 380 U.S. 300, 312 (1965).

"11 Tony \& Susan Alamo, 471 U.S. at 299. By contrast, five members of the Catholic Bishop Court thought that NLRB jurisdiction over parochial school teachers presented a possibility that the NLRB might in the future be called upon to "go beyond resolving factual issues." 440 U.S. at 502. One possible interpretation of Tony \& Susan Alamo is that its unanimous characterization of the secular activity determination as factual, over the religious organization's objections that the activities were "churches in disguise," simply overruled Catholic Bishop on this point, establishing the factual nature of the inquiry as a matter of law. 
burden imposed.112 The government's compelling interest in labor regulation is well established. ${ }^{113}$ The courts of appeals, through their extension of NLRB jurisdiction to cover the activities of religiously affiliated organizations whose functions have been found to be secular, have implicitly recognized this state prerogative. ${ }^{114}$ This view is further supported by the established principle that such important fair labor statutes as Title VII and the Fair Labor Standards Act extend to secular employment activities of religious organizations. ${ }^{115}$

3. Frustration of statutory purpose. Creating an exemption from the NLRA more extensive than that provided by the employee activity test would seriously undermine the means chosen by Congress to combat unfair labor practices. The number of religiously affiliated educational institutions and social service agencies is large enough that if these institutions were allowed to perpetrate unfair labor practices, the detrimental effect would strike a hard blow to the commercial order as well as to individual employees. Exemptions for ministers and analogous religious functionaries do not seriously weaken the effectiveness of the NLRA in achieving commercial order through stable employment relations; but once the exemptions extend to the wide range of activities in which religiously affiliated organizations engage, they render the NLRA ineffective in a significant portion of the economy. ${ }^{116}$

By engaging in secular or commercial activities, religiously affiliated organizations leave the cloister of religion and enter a field in which they must be subject to regulation designed to implement important public policy. As the court of appeals remarked in King's Garden:

It is conceivable that there are many areas in which the pervasive activities of the State justify some special provisions for religion to prevent it from being submerged by an all-embracing secularism. . . . But it hardly follows that the State may favor religious groups when they themselves choose to be sub-

${ }^{112}$ See Mississippi College, 626 F.2d at 488 (compelling state interest may justify overriding free exercise rights).

113 See notes 13-18 and accompanying text above.

11. See notes 19-20 and accompanying text above.

11s See note 21 and accompanying text above.

118 For example, in the Amos cases the church was operating a gymnasium which it opened to the public. Amos I, 594 F.Supp. at 795-96. And in Tony \& Susan Alamo, the "foundation" was operating a wide range of commercial activities. 471 U.S. at 299. 
merged, for profit or power, in the 'all-embracing secularism' of the corporate economy. ${ }^{117}$

\section{The Test Minimizes the Entangling Effect of the Accommodation Inquiry}

This comment has argued that the organizational approach is flawed because the examination of whether an organization is "pervasively religious" is too intrusive and entangles the government in matters of doctrine. But an employee-based approach will not necessarily solve this problem, for it requires a distinction between "religious" and "secular" employment activities, and this inquiry potentially can be just as entangling. ${ }^{118}$

This comment, however, proposes an employee activity test that is minimally intrusive. The test relies on straightforward factual inquiries that the courts are particularly qualified and specifically empowered to make. ${ }^{119}$ The NLRA itself calls for the NLRB to focus on the employee when deciding whether to assert jurisdiction. ${ }^{120}$

1. Was the employee hired from the public marketplace? In most cases, the first step is to decide whether the employee was hired from the public, secular labor market. Where a religious institution has used the public marketplace as a source of workers, relying primarily on ordinary economic incentives, there is no reason why it should be wholly exempt from fair labor statutes while other employers who recruit from the same market are not. ${ }^{121}$

${ }_{117}$ King's Garden, 498 F.2d at 57, quoting Sherbert, 374 U.S. at 422 (Harlan, J., dissenting).

118 For example, consider the complex test enunciated by the district court in Amos I, 594 F.Supp. at 804-16, for determining whether an activity is "religious" or "secular."

119 See text accompanying notes 100-03 above.

${ }^{120}$ See 29 U.S.C. § 151: "protecting the exercise by workers of full freedom of association" (emphasis added).

121 See, e.g., Tony \& Susan Alamo, 471 U.S. at 299; David L. Gregory, The First Amendment Religion Clauses and Labor Employment Law in the Supreme Court, 1984 Term, 31 N.Y.L. Sch. L. Rev. 1, 35-36 (1986) ("Any religious accommodation statute must operate within the permissible constitutional scope of the establishment clause. . . . When operating commercial ventures, religious organizations will not be allowed unconstitutional preference over secular businesses."); King's Garden, 498 F.2d at 57 (broad Title VII exemption gives unconstitutional advantage to religious organizations in their secular or commercial activities).

That such religious organizations are part of the commercial order is further indicated by the fact that many of them easily exceed the minimum level of gross annual revenues that the NLRB has set as discretionary jurisdictional standards. See, e.g., St. Louis Christian Home, $663 \mathrm{~F} .2 \mathrm{~d}$ at 62 (day care center must have at least $\$ 250,000$ in gross annual revenues to qualify for NLRA coverage). Congress explicitly approved the Board's policy in 
To answer this first question, a court need look no further than to ordinary evidence such as placement of want ads in public newspapers (or, on the other hand, in publications distributed solely to communicants of the religious organization) and testimony of the employer and of the employees themselves about the circumstances of hiring. Such testimony would establish how the employee learned of the position and whether the employer made any effort to limit its recruiting to communicants or to applicants motivated primarily by nonmonetary factors. This inquiry relies on everyday, objective facts with no tinge of religious doctrine. Moreover, an unequivocal showing of secular, public recruitment here may clearly establish NLRB jurisdiction without any need for examination of the employee's activity.

The first prong of the test applies only where a preexisting employment relationship is in question. In those cases, the understanding of the parties at the outset of the relationship often provides evidence of the secular nature of the job. Moreover, in such cases application of the first prong of the test helps identify employees who themselves may have regarded their job functions as religious. Such employees would appear to have a lesser equitable claim to the protection of the labor statutes. In situations where there was no preexisting employment relationship, however, the applicant for employment cannot be regarded as having waived the statutory protection to which she otherwise would be entitled. Further, the first prong of the test would yield no useful evidence in such situations. For a Title VII plaintiff alleging unlawful discrimination in hiring, therefore, only the second prong of the test would apply.

2. Does the employee's activity have any counterpart in the secular economy? The second step of the employee activity test allows a religious organization to prove that the activity in question has no counterpart in the secular economy. This would clearly be the case, for instance, for a priest performing sacraments. Surely no counterpart for this service exists in the secular economy; this can be established without reference to the church's theological explanation for the sacraments. Moreover, the nature and scope of various kinds of secular employment activities-which is the key inquiry in the second prong of the proposed employee activity test-are exactly the sorts of issues with which courts and the NLRB have long experience. ${ }^{122}$ 
The case of Tony \& Susan Alamo v. Secretary of Labor ${ }^{123}$ illustrates the opposite situation from one involving a priest. The religious organization in that case derived its income primarily from the activities of its "associates," most of whom were drug addicts, derelicts, or criminals before their rehabilitation by the organization. ${ }^{124}$ The associates operated "service stations, retail clothing and grocery outlets, hog farms, roofing and electrical construction companies, a record-keeping company, a motel, and companies engaged in the production and distribution of candy."125 However, these various enterprises were assertedly different from "ordinary commercial businesses" because they were "infused with a religious purpose" and were operated as "churches in disguise'-vehicles for preaching and spreading the gospel to the public." ${ }^{126}$ Even the employees themselves agreed with this characterization, ${ }^{127}$ but the Supreme Court nevertheless held that the employees were covered by the Fair Labor Standards Act. The Court reasoned that

[t]he characterization of petitioners' businesses, however, is a factual question. . . . The lower courts clearly took account of the religious aspects of the Foundation's endeavors, and were correct in scrutinizing the activities at issue by reference to objectively ascertainable facts concerning their nature and scope. Both courts found that the Foundation's businesses serve the general public in competition with ordinary commercial enterprises, .... and the payment of substandard wages would undoubtedly give petitioners and similar organizations an advantage over their competitors. . . . [T] $]$ he admixture of religious motivations does not alter a business's effect on commerce. ${ }^{128}$

Thus, in Tony \& Susan Alamo the Court recognized the possibility that some activities can be clearly identified as secular without reference to their putative theological connotations. The activities in this case were exactly the sort of activities that the second

Labor Board v. Hearst Publications, 322 U.S. 111 (1944) (coverage of newsboys).

123471 U.S. 290 (1985).

124 Id. at 292.

125 Id. (footnote omitted).

${ }^{228}$ Id. at $298-99$.

127 Id. at 302 .

${ }^{128}$ Id. at 299 (citations omitted). Although the Court referred to the "businesses" of the Foundation, its opinion makes it clear that it was analyzing individual employee activities of the Foundation; the fact that these activities may have been conducted by different corporate shells in various states played no part in the Court's analysis. Id. at 292. 
step of the proposed employee activity test would have characterized as secular, because their only claim to non-secular status depended on the particular theology of the religious organization. Moreover, a unanimous Court recognized that characterization of these activities was "a factual question," religious organization's argument that the way in which the activities were performed imbued them with a religious character.

Of course, it seems silly to claim that hog farming is a religious activity. How would a closer case-such as that of an instructor at a parochial school-fare under the second part of the employee activity test? The answer requires a careful look at the teacher's activities. For example, a teacher who concentrates on explaining the relationship between the religious organization that employs him and its communicants, or a minister explicitly claiming to perform an intermediary function between the communicants and God, is performing an activity that cannot be identified in the ordinary secular economy. Such a teacher would be exempt from NLRB jurisdiction under the second part of the employee activity test, absent a very strong contrary showing on the first prong.

On the other hand, a teacher of mathematics who claimed that his work was part of a religious ministry would be no different than the hog farmers in Tony \& Susan Alamo. It is impossible to distinguish his activity from that of a public school mathematics teacher except by reference to the theology of his religion. However, a biology teacher who rejects the theory of natural selection in favor of a fundamentalist Christian view, for example, would be distinguishable from biology teachers in the ordinary secular economy on grounds of failure to teach natural selection. Once again, it is unnecessary to inquire into the theology of creationism to reach this conclusion; the observation that an ordinary biology curriculum is not being taught is sufficient. Thus, even in close cases, both steps of the test can be used without entanglement in theological questions.

Applying the employee activity test to the facts in Amos (the case involving the constitutionality of the Title VII exemption), the first prong asks: did the Mormon church solicit any of the plaintiff employees from the public, money economy? At the outset, there were eight plaintiffs involved in these actions. All were former employees of three Mormon church enterprises. The only remaining plaintiff, appearing on appeal as the sole respondent, is

129 See note 111 above. 
Mr. Mayson, who was employed as a building engineer at the Deseret Gymnasium, a public gymnasium that is church owned and operated. ${ }^{130}$ The exact circumstances under which Mr. Mayson was hired remain unclear from the lower court opinions. Thus, application of the first prong of the employee activity test is impossible on the current record.

The second prong of the employee activity test asks whether the employees were performing functions distinguishable from those performed in secular settings only by reference to the theology of the Mormon church. Once again, because the Amos court focused on the relationship between the purpose of the institution and the employee's activity, the district court opinions failed to investigate this area as fully as would have been desirable. However, Mr. Mayson is described as "responsible for maintaining the physical facility at the gymnasium," $"$ and there is no indication in the record as it stands that his job was distinguishable from that of any other building engineer. In fact, the Mormon church's brief in the Supreme Court does not even attempt to argue that Mr. Mayson performed any religious activities; it describes him only as "a building engineer responsible for maintaining the facilities and supervising fourteen parking lot attendants."132 Thus, it seems probable that the employee activity test would extend coverage over Mr. Mayson, providing he was hired from the public sector. However, in light of the incomplete record, a remand might be the best approach in this case.

The employee activity test proposed here avoids entanglement in theological questions largely by refusing to take cognizance of religious organizations' claims that certain jobs are "religious" in nature even though they have analogs in secular organizations. This disposition is in some tension with the courts' approach in other contexts: there, the recognition that "[c]ourts are not arbiters of scriptural interpretation"133 leads the courts to be quite liberal in accepting claims that beliefs, practices, or activities are "religious." "134 However, this approach is in accord with the Court's

130 Amos I, 594 F.Supp. at 795-96.

131 Id. at 796.

${ }^{132}$ Brief for Appellants at 9, submitted January 5, 1987, in Corporation of Presiding Bishop v. Amos, Nos. 86-179 and 86-401, probable jurisdiction noted, 107 S. Ct. 396.

${ }^{133}$ Thomas, 450 U.S. at 716.

134 See, e.g., Thomas, 450 U.S. at 713-16 ("religious beliefs need not be acceptable, logical, consistent, or comprehensible to others in order to merit First Amendment protection"); United States v. Seeger, 380 U.S. 163 (1965) (construing draft exemption for religious objectors to extend to individual who did not believe in a supreme being, on ground that to limit 
views in Tony \& Susan Alamo. Moreover, in Thomas v. Review Bd, Ind. Empl. Sec. Div. and United States v. Seeger-the leading cases giving lenient treatment to claims that behavior was religiously motivated-the religious beliefs in question, while perhaps not susceptible to logical analysis, did give rise to behavior distinguishable from that encountered in ordinary secular life. The purpose of the organizational test is not to penalize such distinguishable (though perhaps inexplicable) behavior, but to screen out behavior which is not distinguishable from ordinary secular life. The need for such a distinction has long been recognized, for example in cases where religious organizations claim tax exemptions for their activities. ${ }^{135}$

The proposed employee activity test actually permits the religious organization to exercise broader powers over its religious employees. Under the organizational test, if an institution was found to be pervasively secular, even an employee who was engaged in a religious activity could come under the aegis of the NLRB. ${ }^{136}$ In comparison, the employee activity test would permit any organization-whether "religious" in character or not-to remove religious employment activities from the state's regulatory authority by filling their need for workers through specialized, religious channels. ${ }^{197}$

Similarly, use of the proposed employee activity test in the context of the NLRA would avoid a violation of the establishment clause. In assessing each employee's function, the state would not be interfering with the free exercise rights by extending its jurisdiction over ministers, who would in most cases be excluded from coverage under both prongs of the proposed test. Simultaneously, the religious organization in question would not be permitted to exempt itself from the statute with regard to its secular employment activities and thereby establish a religion.

the exemption would give a preference to those who believed in a conventional God).

19s See discussion of Lee in text above at notes 55-57.

156 In Bayamon, for example, several Dominican priests were included in the certified bargaining unit when the organizational test was applied. $793 \mathrm{~F} .2 \mathrm{~d}$ at 391 . In comparison, under the employee activity test proposed here, the priests' functions probably would be deemed nonsecular and thus would be excluded from NLRA coverage.

${ }^{137}$ For example, in St. Elizabeth Community Hospital, although the hospital's primary mission was to fulfill the health care needs of the community, some Sisters of Mercy continued to perform religious employment activities and were precluded from coverage under the NLRB. 708 F.2d at 1441. Such situations cause trouble under the organizational test. On the other hand, the employee activity test seems an especially equitable approach with respect to those churches or religious organizations that, in attempting to meet community needs, have become secular in nature while preserving some vestiges of religious employment activity. 


\section{Conclusion}

The courts of appeals decisions have interpreted Catholic Bishop to require, or at least to allow, an inquiry into the nature of the religious organization to determine whether the NLRB has jurisdiction. If an institution is deemed "pervasively religious," it is exempt from NLRB jurisdiction. Otherwise, it is not. This organizational approach to accommodation presents several constitutional problems: it is overinclusive in that it exempts employees in secular, commercial activities where no rights of religious exercise are at stake; it is underinclusive in that it fails to protect employees performing truly religious functions in secular organizations; and it impermissibly entangles government in matters of theology by requiring a determination as to which organizations are "religious" and which are not. Finally, the judicially created accommodation of whole organizations runs counter to Congress's permissible, employee-based accommodation embodied in section 19 of the NLRA.

To avoid these constitutional problems and to coordinate judicial accommodation with Congress's orientation in section 19, courts should focus on employees' activities in fashioning exemptions from the NLRA and other labor statutes. The proper question is whether the religious institution has solicited the employee from the public marketplace to perform a secular function. If so, the religious institution is obligated to comply with the NLRA with regard to its secular employment activities. If not, the second inquiry is triggered. Is the job distinguishable from secular activities only by reference to the theology of the religious organization? If so, labor regulation is appropriate. Only if the overall answer to these inquiries is negative is exemption from regulation justifiable.

Elizabeth Tucker Bradley 